\title{
Bizionia paragorgiae gen. nov., sp. nov., a novel member of the family Flavobacteriaceae isolated from the soft coral Paragorgia arborea
}

Correspondence

Olga I. Nedashkovskaya

olganedashkovska@yahoo.com

\author{
Olga I. Nedashkovskaya, ${ }^{1}$ Seung Bum Kim, ${ }^{2} \dagger$ Anatoly M. Lysenko, ${ }^{3}$ \\ Galina M. Frolova, ${ }^{1}$ Valery V. Mikhailov ${ }^{1}$ and Kyung Sook Bae ${ }^{2}$ \\ ${ }^{1}$ Pacific Institute of Bioorganic Chemistry of the Far-Eastern Branch of the Russian Academy
of Sciences, Pr. 100 Let Vladivostoku 159, 690022, Vladivostok, Russia
}

${ }^{2}$ Korean Collection for Type Cultures, Biological Resources Center, Korea Institute of Bioscience and Biotechnology, Yusong, Daejon 305-333, Republic of Korea

${ }^{3}$ Institute of Microbiology of the Russian Academy of Sciences, Pr. 60 let October 7/2, Moscow, 117811, Russia

\begin{abstract}
A novel marine bacterium isolated from the soft coral Paragorgia arborea in the Sea of Okhotsk was studied by using a polyphasic taxonomic approach. The strain, KMM 6029 ${ }^{\top}$, was strictly aerobic, heterotrophic, yellow-pigmented, non-motile by gliding, Gram-negative and oxidase-, catalase- and alkaline phosphatase-positive. From results of $16 \mathrm{~S}$ rRNA gene sequence analysis, strain KMM $6029^{\top}$ occupied a distinct lineage within the family Flavobacteriaceae and showed $95.5 \%$ similarity to its closest relative, Formosa algae. The DNA G + C content was $37 \cdot 6 \mathrm{~mol} \%$. Major respiratory quinone was MK-6. The predominant fatty acids were i15:0, a15:0, i15: 1, a15: 1, i16:1, i16:0, i16:0 3-OH and summed feature 3 (i15:0 2-OH and/or $16: 1 \omega 7 c)$. On the basis of phenotypic, chemotaxonomic, genotypic and phylogenetic characteristics the novel bacterium has been assigned to Bizionia gen. nov., as Bizionia paragorgiae gen. nov., sp. nov. The type strain is KMM $6029^{\top}\left(=\mathrm{KCTC} 12304^{\top}=\mathrm{LMG} 22571^{\top}\right)$.
\end{abstract}

Members of the family Flavobacteriaceae are often found in various marine habitats. Many novel representatives of this group inhabiting the Sea of Japan have been isolated and described recently (Suzuki et al., 2001; Nedashkovskaya et al., 2003b, c, 2004a, b; Sohn et al., 2004). Little is known about the diversity of flavobacteria that live in the waters of the north-western Pacific.

In the course of a study of the microbial population of the soft coral Paragorgia arborea, which inhabits the Sea of Okhotsk (Pacific Ocean), a novel heterotrophic, aerobic, yellow-pigmented, non-gliding, Gram-negative bacterium was isolated. By using $16 \mathrm{~S}$ rRNA gene sequence phylogenetic analysis, the unknown strain was determined to be a member of the family Flavobacteriaceae, in which it forms a distinct lineage. Based on differences in molecular, fatty acid composition and phenotypic features described

Published online ahead of print on 10 September 2004 as DOI 10.1099/ijs.0.63381-0.

†Present address: Department of Microbiology, School of Bioscience and Biotechnology, Chungnam National University, Yusong, Daejon 305-764, Republic of Korea.

The GenBank/EMBL/DDBJ accession number for the 16S rRNA gene sequence of Bizionia paragorgiae KMM 6029 ${ }^{\top}$ is AY651070. in this study, we propose the description of Bizionia paragorgiae gen. nov., sp. nov., with KMM $6029^{\mathrm{T}}$ (= KCTC $12304^{\mathrm{T}}=\mathrm{LMG} 22571^{\mathrm{T}}$ ) as the type strain.

Strain KMM $6029^{\mathrm{T}}$ was isolated from the soft coral Paragorgia arborea collected from Makarov Bay, Iturup Island, Kurile Islands, Sea of Okhotsk, Pacific Ocean, from a depth of $120 \mathrm{~m}$ during September 1997. For strain isolation, $0.1 \mathrm{ml}$ tissue homogenate was transferred to marine agar plates. After primary isolation and purification, strains were cultivated at $28{ }^{\circ} \mathrm{C}$ on the same medium and stored at $-80{ }^{\circ} \mathrm{C}$ in marine broth supplemented with $20 \%(\mathrm{v} / \mathrm{v})$ glycerol.

Genomic DNA extraction, PCR and sequencing of the 16S rRNA gene followed previously described procedures (Kim et al., 1998). The sequence data obtained were aligned with those of representatives of the family Flavobacteriaceae using PHYDIT version 3.2 (http://plaza.snu.ac.kr/ jchun/ phydit/). Phylogenetic trees were inferred using appropriate programs in the PHYLIP package (Felsenstein, 1993). Phylogenetic distances were calculated from the models of Kimura (1980) and trees were constructed using neighbourjoining (Saitou \& Nei, 1987), least squares (Fitch \& Margoliash, 1967) and maximum-likelihood (Felsenstein, 1993) algorithms. Bootstrap analysis was performed with 


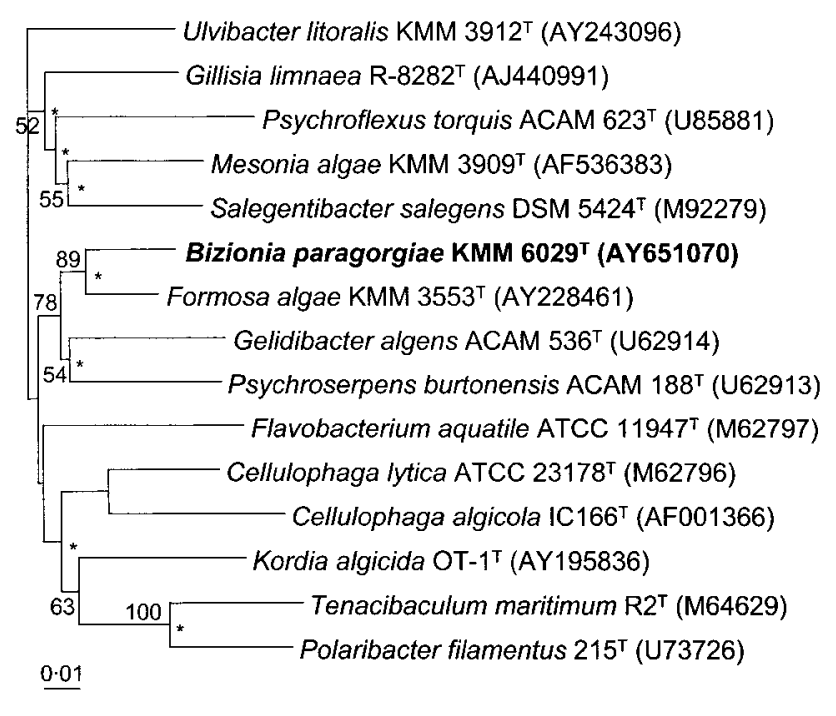

Fig. 1. Phylogenetic tree based on the 16S rRNA gene sequences of strains $\mathrm{KMM} 6029^{\top}$ and representative members of related genera in the family Flavobacteriaceae. The tree was generated by the neighbour-joining method (Saitou \& Nei, 1987). Numbers at nodes indicate bootstrap values (\%) and asterisks indicate branches that were also recovered in the maximum-likelihood tree. Scale bar represents 0.01 substitutions per nucleotide position.

1000 resampled datasets, using SEQBOOT and CONSENSE programs of the PHYLIP package.

Phylogenetic 16S rRNA gene sequence analysis revealed that strain KMM $6029^{\mathrm{T}}$ is a member of the family Flavobacteriaceae and forms a cluster with species of the genera Formosa, Gelidibacter and Psychroserpens (Fig. 1). The nearest neighbour of this strain is Formosa algae KMM $3553^{\mathrm{T}}$, with $95.5 \% 16 \mathrm{~S}$ rRNA gene sequence similarity, without significant bootstrap support. Sequence similarities between KMM $6029^{\mathrm{T}}$ and other close relatives ranged from 89.9 to $92.9 \%$.

DNA was isolated following the method of Marmur (1961) and the $\mathrm{G}+\mathrm{C}$ content of the DNA was determined by the thermal denaturation method (Marmur \& Doty, 1962); the $\mathrm{G}+\mathrm{C}$ content of the DNA was $37 \cdot 6 \mathrm{~mol} \%$.

Analysis of fatty acid methyl esters was carried out according to the standard protocol of the Microbial Identification System (Microbial ID). Major cellular fatty acids were i15:0 (13.2\%), a15:0 (12.3\%), i15: 1 (9.4\%), a15: 1 $(5 \cdot 8 \%), \mathrm{i} 16: 1(5 \cdot 4 \%), \mathrm{i} 16: 0(5 \cdot 8 \%), \mathrm{i} 16: 03-\mathrm{OH}(6 \cdot 8 \%)$ and summed feature $3(6 \cdot 3 \%)$, comprising i15:0 2-OH and/or $16: 1 \omega 7 c$. It should be noted that cells of strain KMM $6029^{\mathrm{T}}$ contained $77 \cdot 1 \%$ branched fatty acids. Isoprenoid quinones were extracted from lyophilized cells and analysed as described previously (Nedashkovskaya et al., 2003c). The major respiratory quinone was MK-6.

Phenotypic analysis was performed by using previously described methods (Nedashkovskaya et al., 2003a, b). Gliding motility was determined as described by Bowman (2000). The physiological, biochemical and morphological characteristics of strain KMM $6029^{\mathrm{T}}$ are listed in the species description and Table 1. The results of phenotypic analysis demonstrated many common traits between strain KMM $6029^{\mathrm{T}}$ and Formosa algae. However, strain KMM $6029^{\mathrm{T}}$ clearly differs from its closest relative by the inability to move by gliding, to form acid from carbohydrates, to hydrolyse starch and casein, and to produce hydrogen sulphide from L-cysteine (Table 1). The main phenotypic

Table 1. Differential characteristics for Bizionia paragorgiae gen. nov., sp. nov. and other members of the family Flavobacteriaceae

Taxa: 1, Bizionia gen. nov.; 2, Formosa; 3, Algibacter; 4, Gelidibacter; 5, Psychroserpens; 6, Polaribacter. -, Negative; +, positive; V, variable; NG, no growth. Data were taken from Reichenbach (1989), Bowman et al. (1997), Gosink et al. (1998), Macián et al. (2002), Ivanova et al. (2004), Nedashkovskaya et al. (2004b) and this study.

\begin{tabular}{|c|c|c|c|c|c|c|}
\hline Characteristic & 1 & 2 & 3 & 4 & 5 & 6 \\
\hline Metabolism & A & A & $\mathrm{F}$ & A & A & A \\
\hline Gliding motility & - & + & + & + & - & - \\
\hline Oxidase activity & + & + & + & - & - & $\mathrm{V}$ \\
\hline Requirement for $\mathrm{Na}^{+}$for growth & + & - & + & + & + & + \\
\hline Acid formation from carbohydrates & - & + & + & + & - & + \\
\hline \multicolumn{7}{|l|}{ Hydrolysis of: } \\
\hline Agar & - & - & + & - & - & - \\
\hline Casein & + & - & - & $\mathrm{V}$ & + & NG \\
\hline Starch & - & + & $\mathrm{V}$ & + & - & + \\
\hline $\mathrm{H}_{2} \mathrm{~S}$ production & + & - & - & - & - & - \\
\hline DNA G $+\mathrm{C}$ content $(\mathrm{mol} \%)$ & $37 \cdot 6$ & $34-35$ & $31-33$ & $36-40$ & $27-29$ & $31-33$ \\
\hline
\end{tabular}

${ }^{\star}$ A, Aerobic; F, fermentative. 
characteristics that differentiate strain KMM $6029^{\mathrm{T}}$ clearly from other relatives of the family Flavobacteriaceae are shown in Table 1. Significantly, Formosa algae KMM $3553^{\mathrm{T}}$ is characterized by the presence of $17: 0$ and $19: 0$ cyclo fatty acids and the absence of i17:0 3-OH (Ivanova et al., 2004), lending further support to the creation of a new genus for strain KMM $6029^{\mathrm{T}}$.

Consequently, based on the phylogenetic distinctiveness and significant differences in phenotypic features and cellular fatty acid composition, we propose that strain KMM $6029^{\mathrm{T}}$ should be differentiated from its nearest neighbour, Formosa algae. Thus, the results of the polyphasic taxonomic analysis presented in this study support the placement of strain KMM $6029^{\mathrm{T}}$ in a new genus, Bizionia gen. nov., as Bizionia paragorgiae sp. nov.

\section{Description of Bizionia gen. nov.}

Bizionia (Bi.zi.o' ni.a. N.L. fem. n. Bizionia of Bizio, named in honour of the famous Italian naturalist Bartolomeo Bizio, for his important contribution to the development of microbiology).

Rod-shaped cells, non-motile by gliding. Gram-negative. Do not form endospores. Strictly aerobic. Produce nondiffusible carotenoid pigments. Chemo-organotrophs. Cytochrome oxidase-, catalase- and alkaline phosphatasepositive. Major respiratory quinone is MK-6. Major cellular fatty acids are straight-chain unsaturated and branchedchain unsaturated fatty acids i15:0, a15:0, i15:1, a15:1, i16: 1, i16:0, i16:0 3-OH and summed feature 3 (i15:0 $2-\mathrm{OH}$ and/or $16: 1 \omega 7 c$ ). As determined by $16 \mathrm{~S}$ rRNA gene sequence analysis, the genus is a member of the family Flavobacteriaceae. The type species is Bizionia paragorgiae.

\section{Description of Bizionia paragorgiae sp. nov.}

Bizionia paragorgiae (pa.ra.gor'gi.ae. N.L. gen. n. paragorgiae of the generic name of the soft coral Paragorgia arborea, from which the type strain was isolated).

Main characteristics are as given for the genus. In addition, cells are $0 \cdot 4-0 \cdot 5 \mu \mathrm{m}$ wide and $1 \cdot 9-2 \cdot 3 \mu \mathrm{m}$ long. On marine agar colonies are $2-4 \mathrm{~mm}$ in diameter, circular, shiny with entire edges, yellow pigmented. Growth is observed at $4-36{ }^{\circ} \mathrm{C}$. Optimal temperature for growth is $23-25^{\circ} \mathrm{C}$. Growth occurs at $1-8 \% \mathrm{NaCl}$. Decomposes casein, gelatin, Tween 40 and Tween 80 . Does not degrade agar, starch, DNA, urea, Tween 20, cellulose (CM-cellulose or filter paper) or chitin. Does not form acid from L-arabinose, D-cellobiose, L-fucose, D-galactose, D-glucose, D-lactose, D-maltose, D-melibiose, L-raffinose, L-rhamnose, D-sucrose, DL-xylose, citrate, adonitol, dulcitol, glycerol, inositol or mannitol. Does not utilize L-arabinose, D-glucose, D-lactose, D-mannose, D-sucrose, mannitol, inositol, sorbitol, malonate or citrate. Nitrate is not reduced. $\mathrm{H}_{2} \mathrm{~S}$ is produced. Indole and acetoin (Voges-Proskauer reaction) production are negative. Cellular fatty acids accounting for more than $1.0 \%$ of the total fatty acid content are i14:0 (2.5\%), i15: $1(9 \cdot 4 \%)$, a15: $1(5 \cdot 8 \%)$, i15:0 (13.2\%), a15:0 (12.3\%), $15: 0(4 \cdot 3 \%), 15: 1 \omega 6 c$ $(1 \cdot 3 \%)$, i16:1 (5.4\%), i16:0 (5.8\%), $16: 0(3 \cdot 4 \%), \mathrm{i} 15: 0$ $3-\mathrm{OH}(3 \cdot 4 \%)$, a17 : $0(3 \cdot 7 \%), \mathrm{i} 17: 1 \omega 9 c(1 \cdot 7 \%)$, a $17: 1 \omega 9 c$ $(1 \cdot 5 \%), \quad 17: 1 \omega 6 c(1.9 \%), \quad \mathrm{i} 16: 0 \quad 3-\mathrm{OH}(6 \cdot 8 \%), \mathrm{i} 17: 0$ $3-\mathrm{OH}(4 \cdot 3 \%)$ and summed feature $3(6 \cdot 3 \%)$, comprising $16: 1 \omega 7 c$ and/or i $15: 02-\mathrm{OH}$ fatty acids. The $\mathrm{G}+\mathrm{C}$ content of the DNA is $37 \cdot 6 \mathrm{~mol} \%$.

The type strain is KMM $6029^{\mathrm{T}}\left(=\mathrm{KCTC} 12304^{\mathrm{T}}=\mathrm{LMG}\right.$ $22571^{\mathrm{T}}$ ), isolated from the soft coral Paragorgia arborea collected in Makarov Bay, Iturup Island, Sea of Okhotsk.

\section{Acknowledgements}

This research was supported by grants of the Federal Agency for Sciences of the Ministry for Education and Sciences of the Russian Federation no. 2-2.16, Russian Foundation for Basic Research no. 05-04-48211 and Presidium of the Russian Academy of Sciences 'Molecular and Cell Biology'. S. B. K. and K. S. B. acknowledge support from the KRIBB Research Initiative Program.

\section{References}

Bowman, J. P. (2000). Description of Cellulophaga algicola sp. nov., isolated from the surfaces of Antarctic algae, and reclassification of Cytophaga uliginosa (ZoBell and Upham 1944) Reichenbach 1989 as Cellulophaga uliginosa comb. nov. Int J Syst Evol Microbiol 50, 1861-1868.

Bowman, J. P., McCammon, S. A., Brown, J. L., Nichols, P. D. \& McMeekin, T. A. (1997). Psychroserpens burtonensis gen. nov., sp. nov., and Gelidibacter algens gen. nov., sp. nov., psychrophilic bacteria isolated from Antarctic lacustrine and sea ice habitats. Int J Syst Bacteriol 47, 670-677.

Felsenstein, J. (1993). PHYLIP (phylogenetic inference package), version 3.5c. Distributed by the author. Department of Genetics, University of Washington, Seattle, USA.

Fitch, W. M. \& Margoliash, E. (1967). Construction of phylogenetic trees: a method based on mutation distances as estimated from cytochrome $c$ sequences is of general applicability. Science 155, 279-284.

Gosink, J. J., Woese, C. R. \& Staley, J. T. (1998). Polaribacter gen. nov., with three new species, $P$. irgensii sp. nov., $P$. franzmannii sp. nov. and $P$. filamentus sp. nov., gas vacuolate polar marine bacteria of the Cytophaga-Flavobacterium-Bacteroides group and reclassification of 'Flectobacillus glomeratus' as Polaribacter glomeratus comb. nov. Int J Syst Bacteriol 48, 223-235.

Ivanova, E. P., Alexeeva, Y. A., Flavier, S., Wright, J. P., Zhukova, N. V., Gorshkova, N. M., Mikhailov, V. V., Nicolau, D. V. \& Christen, R. (2004). Formosa algae gen. nov., sp. nov., a novel member of the family Flavobacteriaceae. Int J Syst Evol Microbiol 54, 705-711.

Kim, S. B., Falconer, C., Williams, E. \& Goodfellow, M. (1998). Streptomyces thermocarboxydovorans sp. nov. and Streptomyces thermocarboxydus sp. nov., two moderately thermophilic carboxydotrophic species isolated from soil. Int J Syst Bacteriol 48, 59-68.

Kimura, M. (1980). A simple method for estimating evolutionary rates of base substitutions through comparative studies of nucleotide sequences. J Mol Evol 16, 111-120.

Macián, M. C., Pujalte, M. J., Márquez, M. C., Ludwig, W., Ventosa, A., Garay, E. \& Schleifer, K. H. (2002). Gelidibacter mesophilus sp. nov., 
a novel marine bacterium in the family Flavobacteriaceae. Int J Syst Evol Microbiol 52, 1325-1329.

Marmur, J. (1961). A procedure for the isolation of deoxyribonucleic acid from microorganisms. J Mol Biol 3, 208-218.

Marmur, J. \& Doty, P. (1962). Determination of the base composition of deoxyribonucleic acid from its thermal denaturation temperature. J Mol Biol 5, 109-118.

Nedashkovskaya, O. I., Suzuki, M., Vysotskii, M. V. \& Mikhailov, V. V. (2003a). Reichenbachia agariperforans gen. nov., sp. nov., a novel marine bacterium in the phylum Cytophaga-FlavobacteriumBacteroides. Int J Syst Evol Microbiol 53, 81-85.

Nedashkovskaya, O. I., Suzuki, M., Vysotskii, M. V. \& Mikhailov, V. V. (2003b). Vitellibacter vladivostokensis gen. nov., sp. nov., a new member of the phylum Cytophaga-Flavobacterium-Bacteroides. Int J Syst Evol Microbiol 53, 1281-1286.

Nedashkovskaya, O. I., Kim, S. B., Han, S. K. \& 7 other authors (2003c). Mesonia algae gen. nov., sp. nov., a novel marine bacterium of the family Flavobacteriaceae isolated from the green alga Acrosiphonia sonderi (Kütz) Kornm. Int J Syst Evol Microbiol 53, 1967-1971.

Nedashkovskaya, O. I., Kim, S. B., Han, S. K., Rhee, M. S., Lysenko, A. M., Falsen, E., Frolova, G. M., Mikhailov, V. V. \& Bae, K. S. (2004a). Ulvibacter litoralis gen. nov., sp. nov., a novel member of the family Flavobacteriaceae isolated from the green alga Ulva fenestrata. Int J Syst Evol Microbiol 54, 119-123.

Nedashkovskaya, O. I., Kim, S. B., Han, S. K. \& 7 other authors (2004b). Algibacter lectus gen. nov., sp. nov., a novel member of the family Flavobacteriaceae isolated from green algae. Int J Syst Evol Microbiol 54, 1257-1261.

Reichenbach, H. (1989). The order Cytophagales Leadbetter 1974, 99 ${ }^{\mathrm{AL}}$. In Bergey's Manual of Systematic Bacteriology, vol. 3, pp. 20112073. Edited by J. T. Staley, M. P. Bryant, N. Pfennig \& J. G. Holt. Baltimore: Williams \& Wilkins.

Saitou, N. \& Nei, M. (1987). The neighbor-joining method: a new method for reconstructing phylogenetic trees. Mol Biol Evol 4, 406-425.

Sohn, J. K., Lee, J. H., Yi, H., Chun, J., Bae, K. S., Ahn, T. Y. \& Kim, S. J. (2004). Kordia algicida gen. nov., sp., nov., an algicidal bacterium isolated from red tide. Int J Syst Evol Microbiol 54, 675-680.

Suzuki, M., Nakagawa, Y., Harayama, S. \& Yamamoto, S. (2001). Phylogenetic analysis and taxonomic study of marine Cytophaga-like bacteria: proposal for Tenacibaculum gen. nov. with Tenacibaculum maritimum comb. nov., and Tenacibaculum ovolyticum comb. nov., and description of Tenacibaculum mesophilum sp. nov. and Tenacibaculum amylolyticum sp. nov. Int J Syst Evol Microbiol 51, 1639-1652. 